\title{
車いす使用者が介助者なしに使用可能な移乗補助具の開発
}

\section{Development of a transfer aid which can be used by a wheelchair user without assistance}

\author{
Yusuke KOBAYASHI $^{* 1}$, Daisuke MIYASHITA ${ }^{* 1}$ and Akihiko NAGASAKA ${ }^{* 1}$ \\ ${ }^{* 1}$ Department of Mechanical Engineering, National Institute of Technology, Nagano College \\ 716 Tokuma, Nagano-shi, Nagano 381-8550, Japan
}

\section{Received 13 March 2015}

\begin{abstract}
A transfer from a wheelchair to bed is difficult for wheelchair users without assistance. Because they must lift their bodies up and move from a wheelchair to bed by themselves. So transfer without assistants puts a strain on them and associated with a risk of fall. Some lifts or assist systems called transfer aids are developed to help transfer, nevertheless they needs assistance. Lifts need large space to use and it is hard to carry. To attach the transfer aids, wheelchair needs to be modified. The aim of our study is to develop a transfer aid which can be used by a wheelchair user without assistance. This transfer aid can attach to wheelchair without improvement. And it can be carried easily so wheelchair users can use it everywhere. The developed transfer aid has the spread mechanism that users feel trouble-free to spread the transfer aid. Only by the simple motion of two axis, wheelchair users can spread the transfer aid. The developed transfer aid succeeded to users transfer themselves. And users can transfer more safely and quickly because the developed transfer aid are attached firmly to a wheelchair. One user can transfer by cross direction by using developed transfer aid who usually transfers by forward direction.
\end{abstract}

Key words : Medical and welfare assistance, Welfarel engineering, Human engineering, Medical engineering, Transfer, Welfare tools, Wheelchair

\section{1. 緒言}

車いす使用者が車いすやベッドなどへ移る動作”移乗動作”は車いす使用者にとって日常生活を送る上で必要 不可欠な動作である。しかし，一人で移乗を行うのは非常に負担となる。一人で移乗を行う場合，移乗者は自身 の体重を腕力だけで支持し，かつ転ばないようにバランスを保ちながら移乗を行わねばならない。一人での移乗 を行えない場合には介助者によるサポートの元で移乗を行う必要がある。その場合には，介助者が移乗者を支持 して移乗を行わねばならず，介助者にかかる負担が非常に大きい.

この移乗動作を補助するために様々な移乗補助具が開発されている. 現状の移乗補助具にはいくつかの種類が あり，大きく分けてボードタイプ，リフトタイプ，車いす付属タイプに大別できる.

ボードタイプの移乗補助具の例として図 1 にトランスファボードを示す。これは移乗者の臀部下にボードを差 し込み，ボードを車いすと移乗先に渡して設置し，その上を，臀部を伝わらせて移乗を行うものである，構造と してシンプルで価格もあまり高くなく，軽量であるため，よく使用される．また，移乗者を持ち上げる必要もな いため介助者にかかる負担も軽減される（勝平他，2010），（佐々木他，2007）。使用に際し車いす側面のアームレ ストが外れる必要がある，従ってアームレストが外れない車いすの場合には使いづらく，前方方向に渡してやや 無理な体勢で使うことになる。また，外出先で移乗を行う場合には持ち運ぶ必要がある。また，臀部の下にボー ドを差し込む動作が必要になる。さらに移乗中にボードがずれると移乗者が落下する危険も伴う。素材として樹 脂が用いられていることが多く，移乗中に変形を伴い不安定な姿勢になることもある，そういったことから一人 での移乗も可能であるが，介助者を伴った使用が好ましい.

No.15-00139 [DOI: 10.1299/transjsme.15-00139], J-STAGE Advance Publication date : 29 October, 2015

*1 正員, (独)国立高等専門学校機構 長野工業高等専門学校 機械工学科（广381-8550 長野県長野市大字徳間 716）

E-mail of corresponding author: koba@nagano-nct.ac.jp 


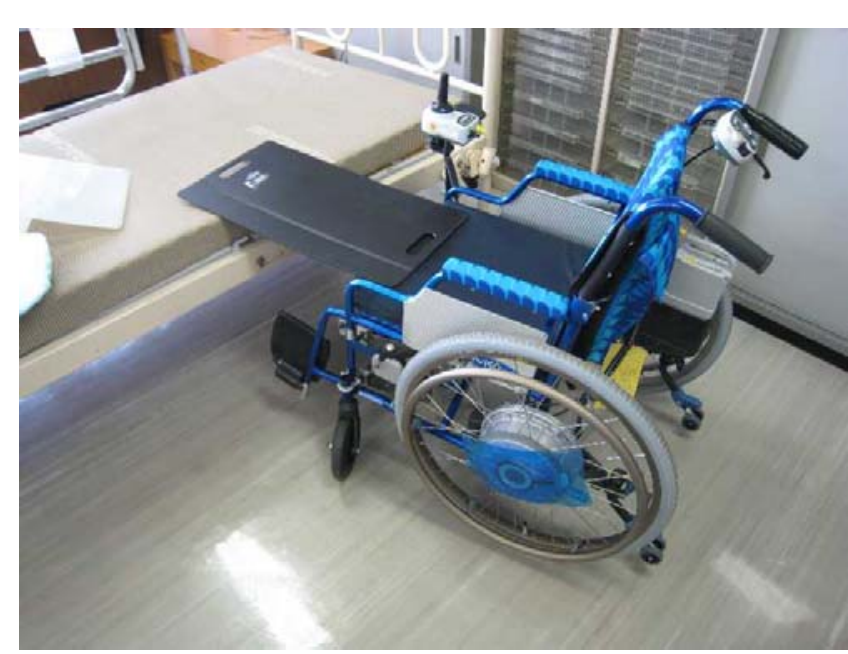

Fig. 1 Transfer board

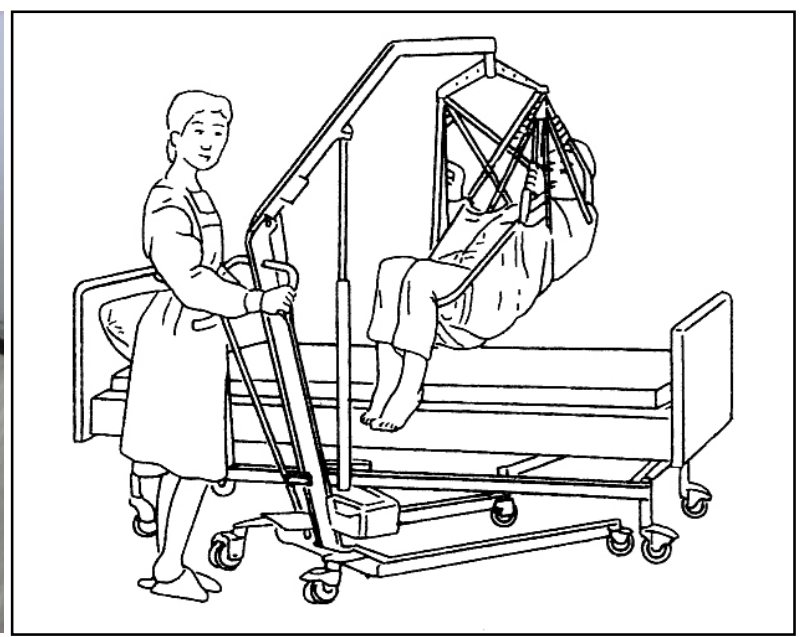

Fig. 2 Transfer by lift

リフトタイプの移乗補助具には図 2 （日本規格協会, 2001）のような介助リフトがある. 介助リフトは移乗者 をリフトで吊して移乗を行う．移乗者にかかる負担は少ないが，リフトそのものが大きく，高額で，半据え置き 型のため持ち運びは不可能である. また，必ず介助者が必要になり，正しい使用を行わないと介助者の身体に負 担がかかる（井上，山崎，2001）。さらに，移乗者の体の下にシートを渡寸必要があるので手間がかかる. 従って 移乗動作自体が大がかりになる.

車い寸付属タイプは，車い寸特有の機能を利用したものである．例えば車いすのアームレストが倒れてトラン スファボードと同じ機能になるようなもの（保健福祉広報協会，2011）である．持ち運びの必要がないが，車い 寸後輪が邪魔にならないように変形，あるいは後ろ方向へずれる必要があり，多くの車い寸にはこの機能はつい ていない.従って,このタイプの移乗補助具を使う際にはこの機能を持った車い寸に買い換えを行う必要がある.

この他の補助具としては,介助者が装着することで移乗介助時の負荷をアシストするロボットスーツ(佐藤他, 2010）や，要介助者がおんぶされるように補助具に体を預け，その補助具ごとキャスタで運ぶタイプ（青野他, 2002），(木下，小泉，2007）などがある. しかしこれらは介助者にかかる負担を軽減させることを念頭におかれ て開発されている. 即ち介助者によるサポートが前提の補助具である.

以上のように，既存の移乗補助具は介助者を要寸ることが多く，あるいは大がかりな物が多いため敬遠されて いる. こういった事から，多くの車い寸使用者は移乗補助具を使わずに，負担のかかる自分の力だけでの動作に よる移乗, あるいは介助者による補助の元での移乗を行っている（茂木他，2012）のが現状である．そこで本研 究では車い寸使用者が一人で容易に移乗を行え, 外出先でも使用可能な移乗補助具の開発を行う。考案した補助 具は車い寸に固定する事で，安定した移乗を行え，また車い寸走行時は収納できるので持ち運びの手間がかから ない。この補助具を実際に試作し，モニ夕評価によりその効果を確かめたので，報告する.

\section{2. 移乗補助具のメカニズム}

\section{$2 \cdot 1$ 求められる機能}

現状の移乗補助具や移乗動作から, 開発する移乗補助具に求められる機能として

・移乗者が一人で移乗を行える

・車いすの改造を必要としない

・持ち運ぶ必要がない

・小型で外出先でも使用可能である

・車い寸の折りたたみ機能を問題なく行える

といった特徵を持つものとした，一人での移乗を実現するためには，移乗中の姿勢が安定している必要がある. 一人での移乗を可能にすることで移乗者, 介助者双方の負担を減らすことができる. 介助者を必要としないこと で, 移乗者が移乗を行いたい時, 介助者の都合を考える必要なく移乗を行える. 特に, 介助者に頼らないと移乗 
できないということから精神的負担や，遠慮して移乗を行わないなどの心理的な問題の解決にもつながる．さら に一人で行動を行える事から積極的な外出の促進となる. これにより筋力低下の防止や外出による精神衛生面の 向上など，二次的な効果も期待される.

車い寸の改造を必要としないということは，現状使っている車い寸をそのまま使い続けることができるという ことになる．車い寸使用者にとって，車い寸は生活を行う上で体の一部のようなものである．従って大半の車い 寸使用者は自分の体や使い方に合うように車い寸をカスタマイズしている，そのため，移乗のために車い寸を買 い替えることは好ましくないと考える，また，様々な機能を有しているため，車い寸に穴を空けるなどの改造に ついても敬遠される．従って現在使っている車い寸に加工などの改造を必要とせずに移乗補助具を使用できる事 が望まれる.

移乗補助具の持ち運びについては，決められた場所のみでの移乗を考える場合には半据え置き型で考えれば問 題ないが，外出先や移動先でも移乗を行う事を考えると携帯性に優れた方が良い．車い寸走行時に手で持ってい ると車いすの操作に影響がでたり，煩わしかったりする．また，大きいと車いすでの走行時に邪魔になる．従っ て，携帯性に優れ，コンパクトである方が良い.

この他に望まれる機能として，多くの車い寸には折りたたみ機能が備わっている．車に乗せるときなどに使用 される機能である. 開発する移乗補助具を車い寸に付加したことで, その折りたたみ機能を損なっては問題であ る. 従って, 折りたたみ機能を阻害することなく使用できる必要がある. 以上の機能を有する移乗補助具として 取り付け型の展開式移乗補助具を提案する.

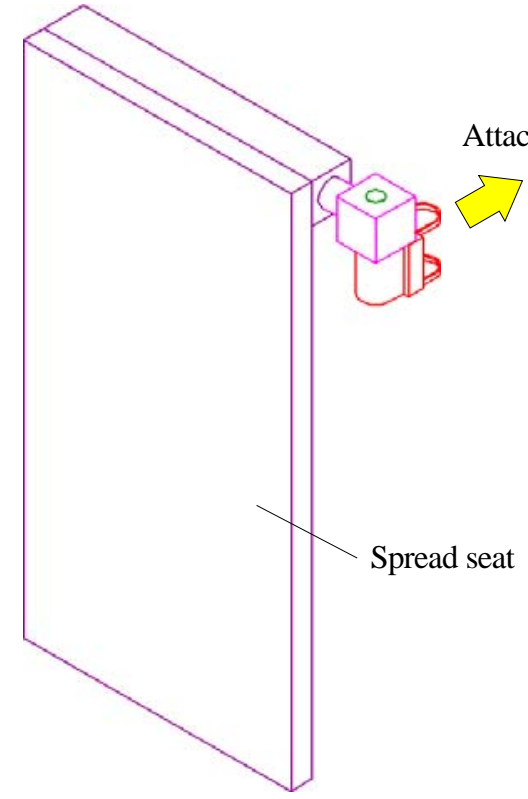

(a) When running

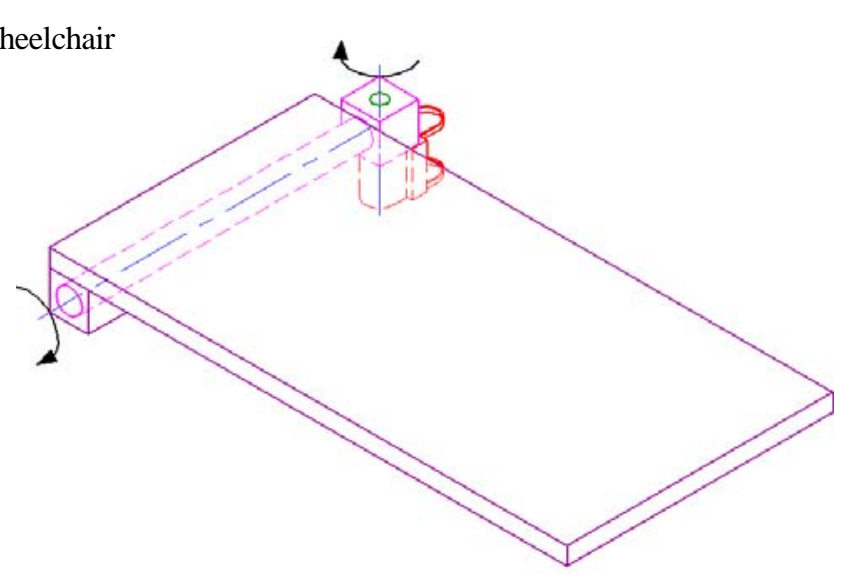

(b) When transfer

Fig. 3 Overview of developed transfer aid

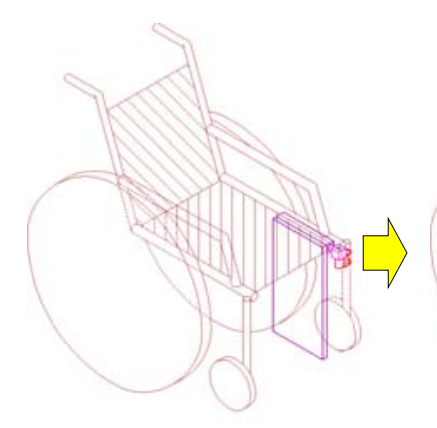

(a) Fold (running)

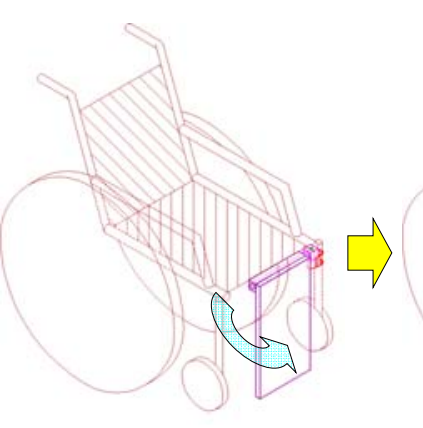

(b) First Spread

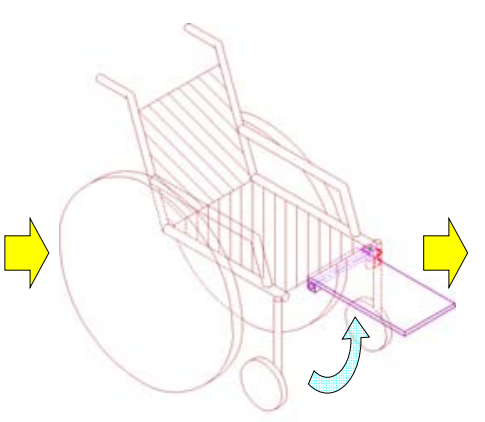

(c) Second Spread

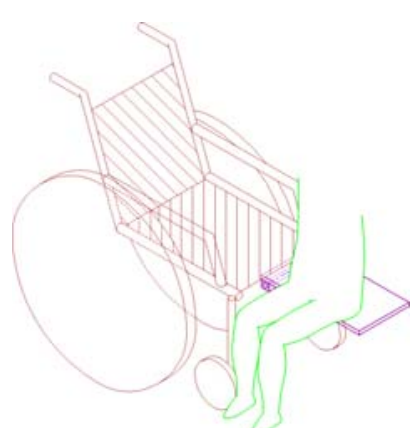

(d) Spread (transfer)

Fig. 4 Motion of spread about transfer aid 


\section{$2 \cdot 2$ 座面の展開・収納}

提案する移乗補助具（小林，2010）を図 3 に示す。この移乗補助具は車いすでの走行時には座面下に収納され ている．移乗時に座面下から車いす正面に拡張座面を展開する．展開した拡張座面の先端を移乗先にのせ，拡張 座面上に慰部をのせて移乗を行う。展開の動作は 2 軸の回転により行う。具体的な展開の様子を図 4 に示す。車 いす座面下から（図 4(a)）まず鉛直軸を中心として回転させ，足元に引き出す（図 4(b)). 次に水平軸を中心とし て上方向に回転させて，車いす座面の延長面上に拡張座面を持ち上げる（図 4(c)). 拡張座面の先端を移乗先にの せて展開が完了となる．移乗者はこの拡張座面の上に臀部をのせて移乗を行う (図 4(d)). 収納はこの動作と逆の 動きにより行われる.

\section{$2 \cdot 3$ 移乗補助具の固定}

提案する移乗補助具は車いすに常時固定しておくものとした．これにより持ち運びの手間がなく，使用の度に 着脱する必要もない，また，固定されているので移乗中に移乗補助具がずれて落下するなどの危険も防げる．移 乗補助具の固定については車いすフレームへの固定を考えた．多くの車いすには図 5 のように，座面を支持する フレームと前輪を支持するフレームがある. メーカーや車いすの種類によってフレーム形状が異なるが，主とな

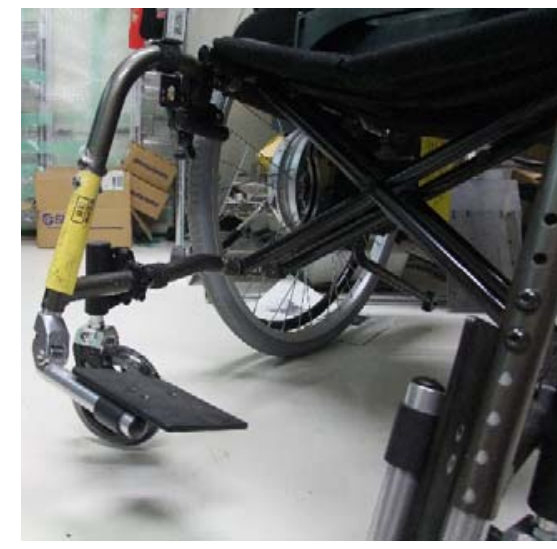

(a) OX ENGINEERING GW-E

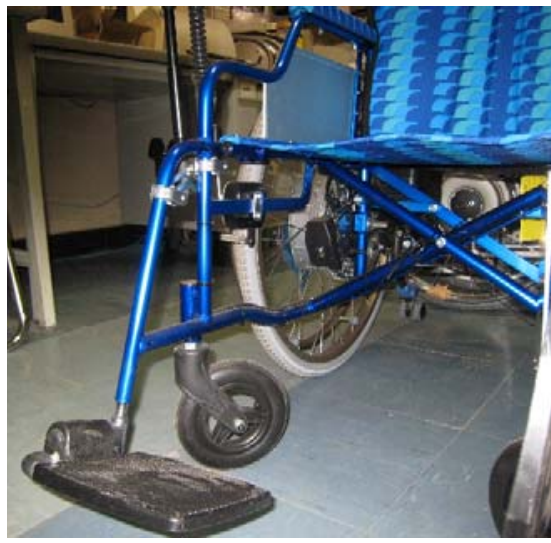

(b) NISSIN MEDICAL INDUSTRIES NA-426AD

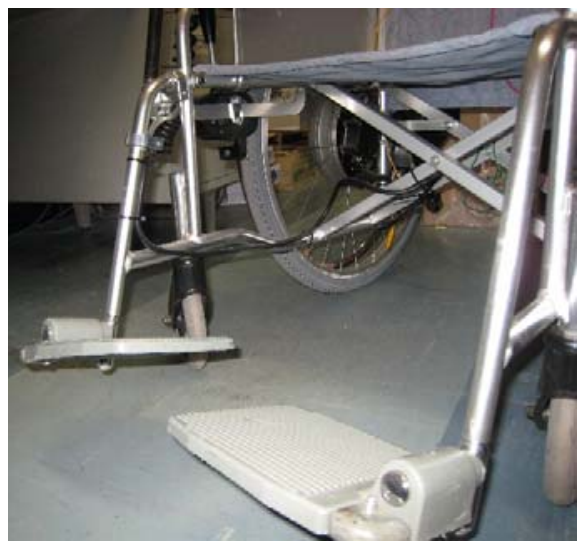

(c) NISSIN MEDICAL INDUSTRIES NA-113A

Fig. 5 Frame of wheelchair around front casters
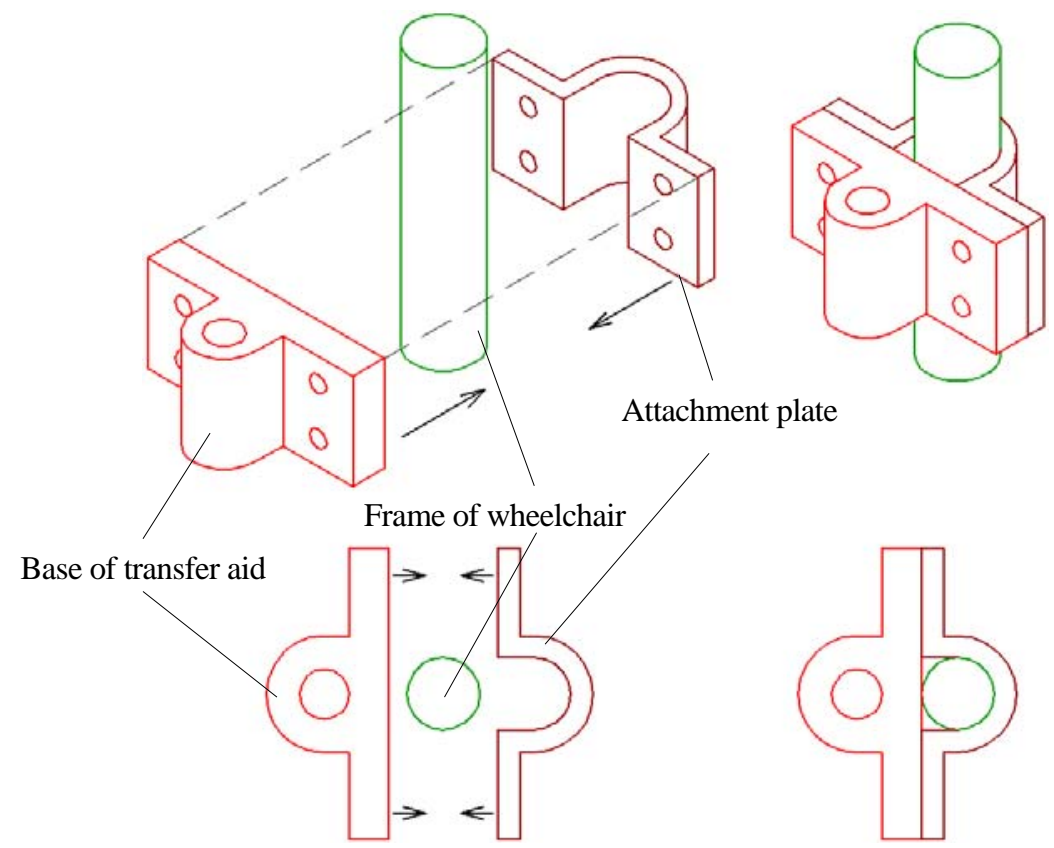

Attachment plate

Fig. 6 Attach mechanism 
るフレーム構造については概ね似た傾向がある，そこで図 6 のように，車い寸フレームに移乗補助具の固定部を 挟み込む形で固定する事にした。 この手法により, 固定は簡単なネジ留めですみ, 車いすへの加工を一切必要と しない. また, フレーム形状やサイズに多少の違いがあっても挟み込む部分の部品交換や部品の追加, 固定部品 の改造で対応が可能である.

\section{3. 設計}

提案する移乗補助具について, 設計を行った。設計した移乗補助具の概要を図 7 に示す，拡張座面の幅を 150 $\mathrm{mm}$, 長さを $400 \mathrm{~mm}$ とした，移乗時の安定性から拡張座面の幅は広い方が良いが，広すぎると展開時に足と干 渉してしまい，移乗動作に支障をきたす，また，長さについては長すぎると収納が困難になるが，短いと移乗距 離が短くなるだけでなく移乗先にのせる部分が短くなり安定性も損なわれる. そこで 2 段の折りたたみ式として 設計を行った．移乗補助具の大きさとしては収納時（図 7(b)）が縦 $230 \mathrm{~mm} \times$ 厚さ $40 \mathrm{~mm}$ となる. 鉛直方向の展 開（図 4(c)）を行うための部品である拡張座面支持部分とそれを支える軸は回転支点となっている. 従って拡張 座面の動作範囲としては水平より上下方向に傾ける事ができるので, 移乗先の高さが車い寸座面と違っていても 対応が可能である．同様に左右方向にも可動できるので，移乗先と車い寸の位置関係を調整でき，負担の少ない

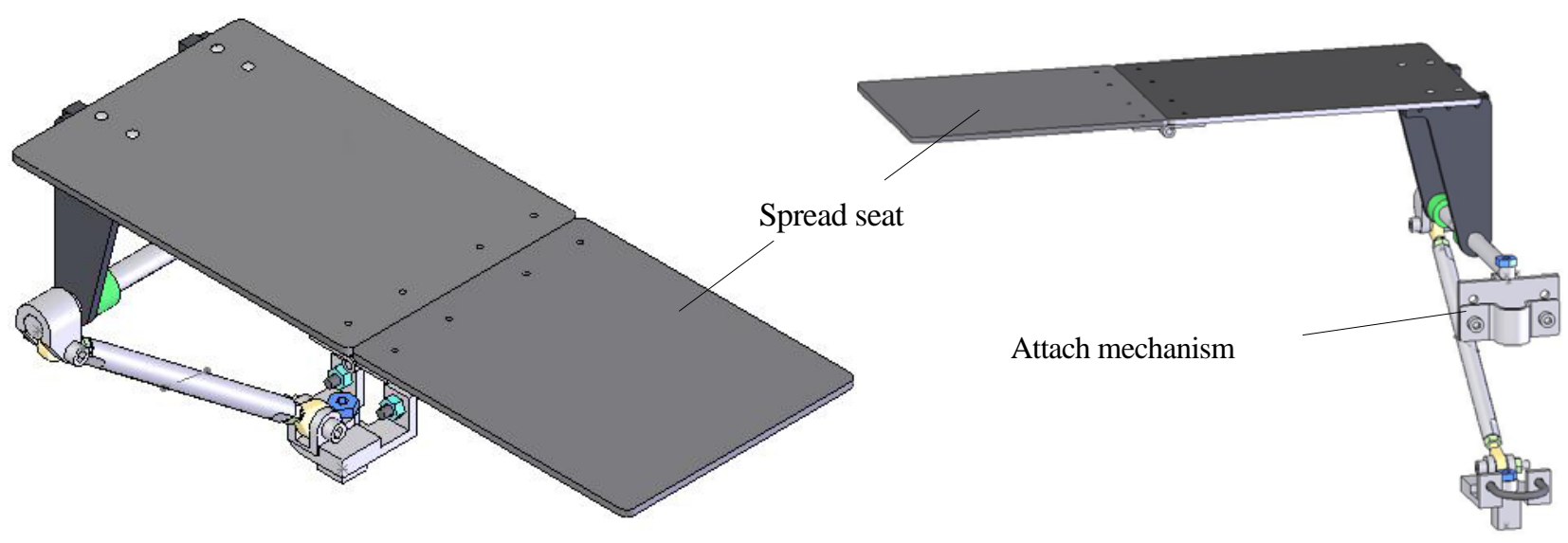

(a) Spread

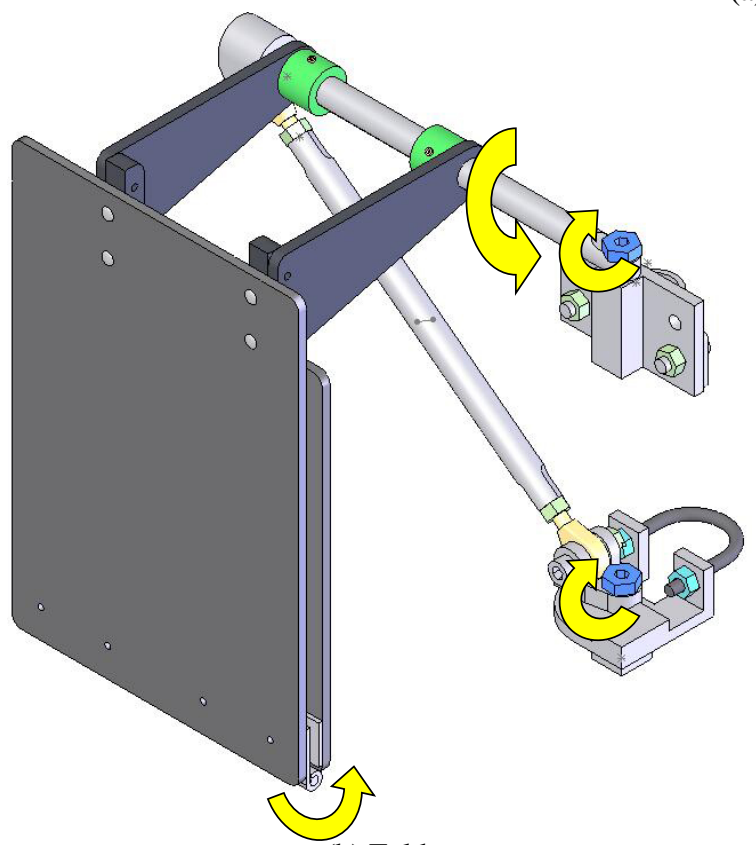

(b) Fold

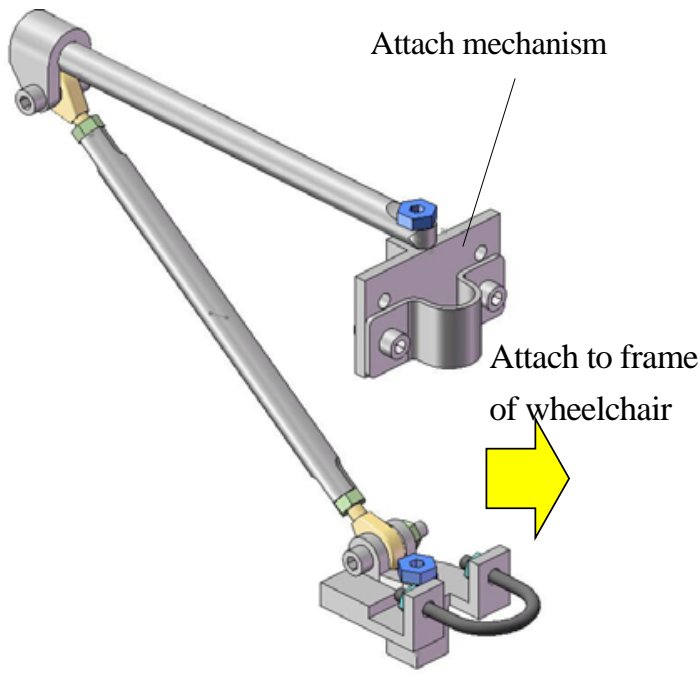

(c) Link of transfer aid

Fig. 7 Design of developed transfer aid 
移乗を可能としている. サイズの異なる車い寸にも対応できるよう, 図 7(c)の三角形状に構成されている移乗補 助具フレームは長さと角度が調整可能である。

\section{4. 応力解析}

\section{$4 \cdot 1$ 解析条件}

設計した移乗補助具の安全性の確認，ならびに負荷がかかった際に各部でどのような応力分布が発生するかを 調べるために力学解析を行った. 解析については設計に使用した Solidworks の 3 次元データを元に, ANSYS に より行った. 解析のための設定としては, メッシュ分割サイズならびにメッシュ数は自動, 要素形状は四面体要 素とした. 拘束条件として, 補助具の拡張座面先端を回転支点として, 拡張座面を支える部品とリンク軸を回転 支点として, 補助具を支えるリンクと車い寸への固定部品を固定支点として指定した. 拡張座面先端については, 実際の使用時にはソファなどの上へ乗せるだけなので，回転支点と考えることができる．また，拡張座面を支え る部品とリンク軸も回転自由で設計してあるので回転支点と考えられる．車い寸との固定部分については，鉛直 方向へは回転できないので，固定端と考えられる，材料指定については，実際の試作に用いる材料を想定し，材 料データベースより, 拡張座面やその他の軽負荷の部品に対してはアルミニウム合金, 軸などの高負荷の係る部 品はステンレス鋼, ネジなどの機械要素については構造用鋼を指定した.

解析条件としては実際に使用する際に影響を及ぼす要素として(1)負荷の大きさ, (2)負荷の位置, (3)負荷面積を それぞれ変えて解析を行った.負荷の大きさとしては移乗者の体重を $70 \mathrm{~kg}(\fallingdotseq 690 \mathrm{~N})$ と想定して, 半分の $350 \mathrm{~N}$, 全体重がかかったときの $690 \mathrm{~N}$, 衝撃荷重として 1.5 倍の $1130 \mathrm{~N}$ の 3 パターンが等分布荷重としてかかった場合 を考えた. 負荷の位置としては図 8 ならびに図 9 に示すように拡張座面の(a)車い寸側, (b)中央, (c)移乗先側の 3 力所を考えた．負荷面積としては図 10 のように(a)手のひら相当, (b)殿部相当, (c)拡張座面半面全体（車い寸側

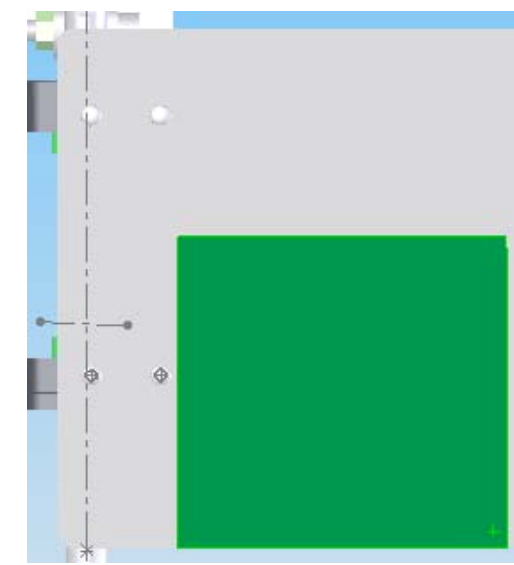

(a) Wheelchair side

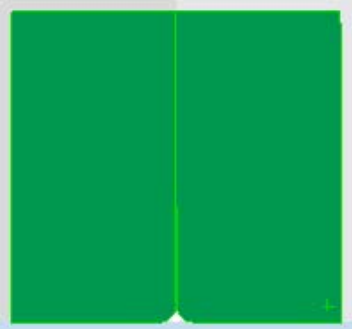

(b) Center

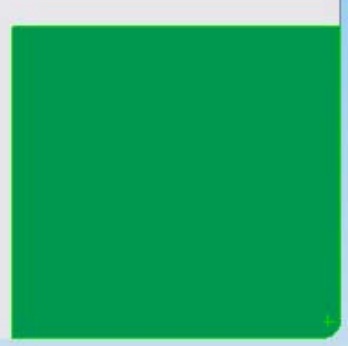

(c) Front side

Fig. 8 Position of the load about palm area

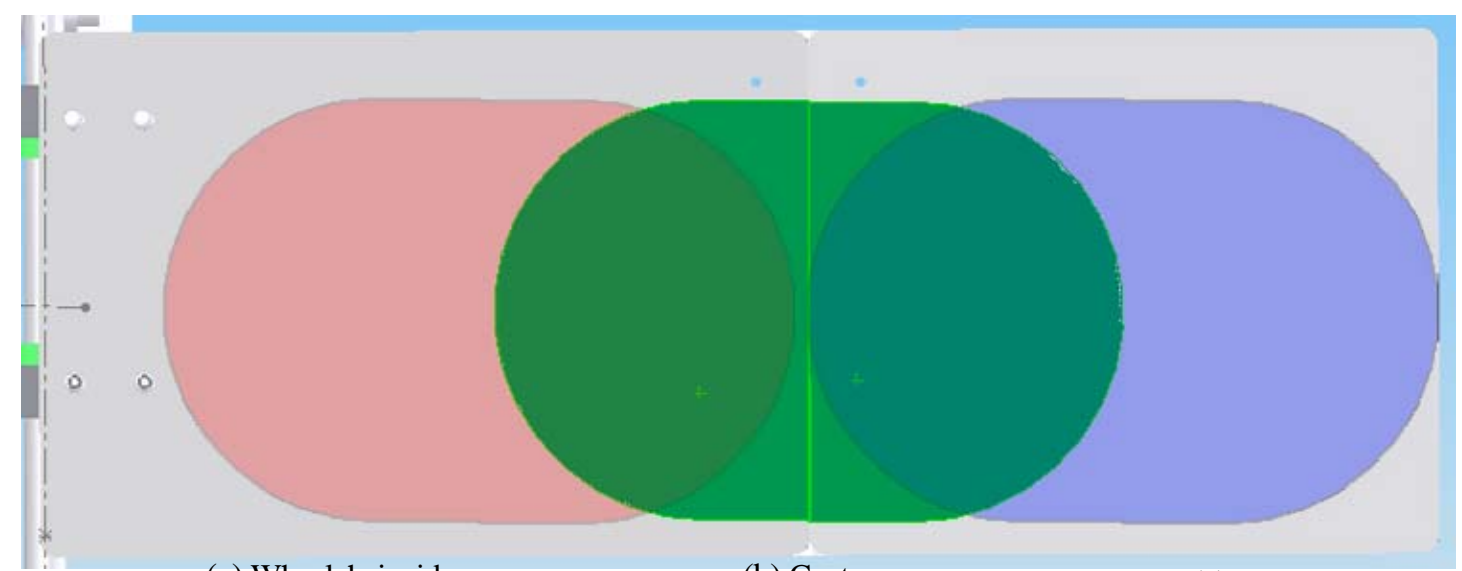

(a) Wheelchair side

(b) Center

(c) Front side

Fig. 9 Position of the load about hip area 


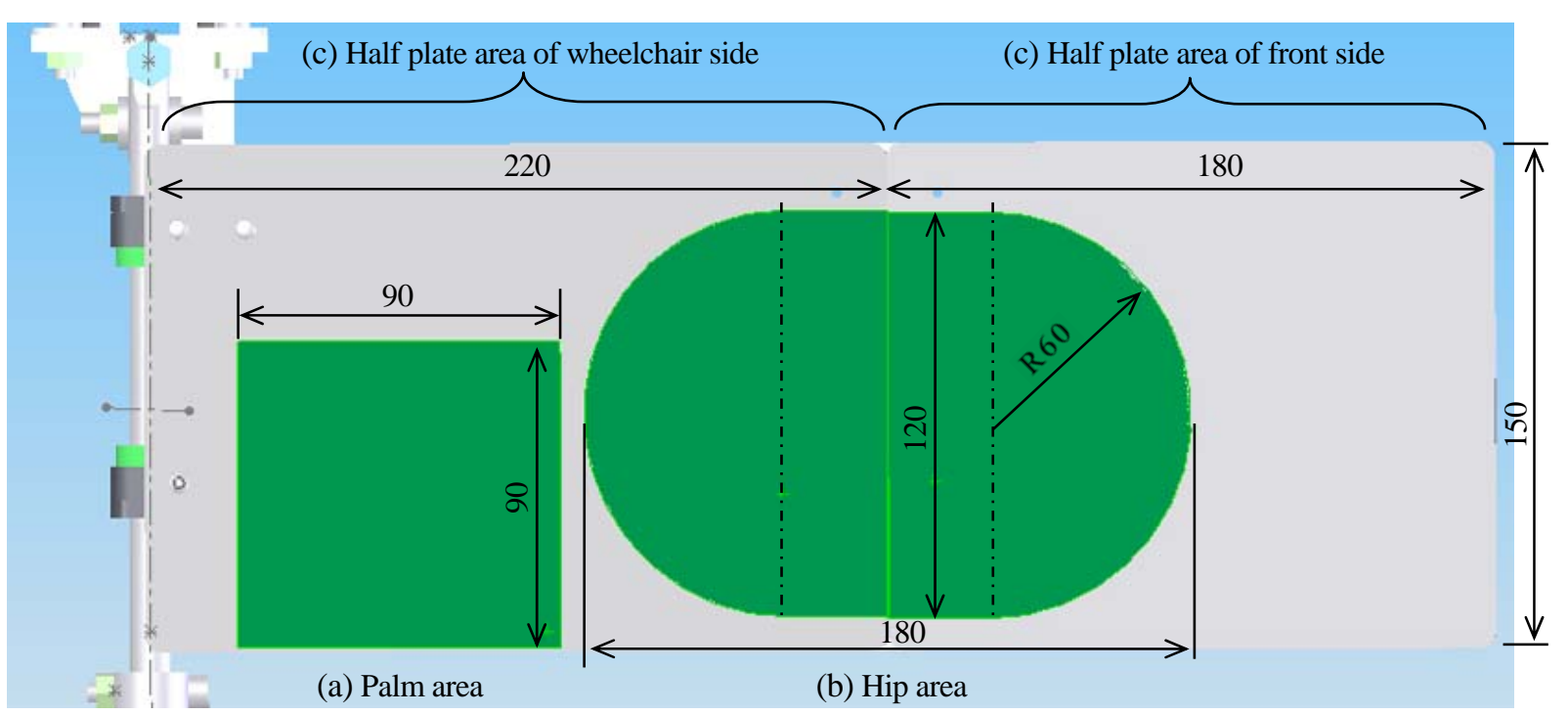

Fig. 10 Area of the load

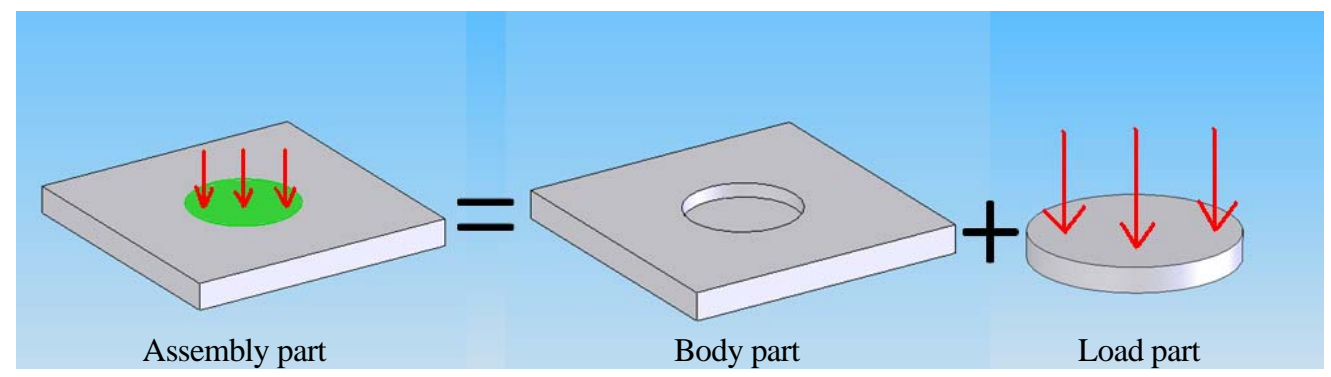

Fig. 11 Specification of the load area

と移乗先側）の3パターンを考えた．移乗を行う際，移乗者は足の取り回しを行いながら移乗する。そのため， 足のある体前方へわずかに重心位置をずらして移乗を行う。また，手の取り回しについてもトランスファボード の端部に沿って手を動かしながら体を支持することがある.そこで，手のひら相当の負荷位置については拡張座 面の端に，臀部相当については中央より $10 \mathrm{~mm}$ ，足のある方へ偏らせた.

ANSYS による解析において，構成部品一面への負荷指定は簡単であるが，部品の任意一部分のみへの負荷指 定は難しく，特に今回のような臀部や手のひらを想定した負荷は指定が非常に困難である. そこで，図 11 のよう に負荷したい形状部分をあらかじめ別部品として 3 次元 CAD データを作成し, それらを 3 次元 CAD 上で合致さ せて，1 つの部品として認識させた. 負荷指定する際には負荷したい形状の部品に負荷指定を行う事で容易に任 意形状への負荷指定を行える.

\section{$4 \cdot 2$ 解析結果と考察}

各条件の元で解析を行った．拡張座面半面に負荷をかけた場合の結果を表 1 に，手のひら相当の面積に負荷が かかった場合を表 2 に, 臀部面積に負荷がかかった場合を表 3 に示す.また, 解析結果の代表を図 12 ならびに図 13 に示す.ほとんどの条件下で安全率が 1.0 を上回った。しかし，補助具中央部分に片手で $1130 \mathrm{~N}$ かけた場合に のみ安全率が 0.9 となり，1.0 を下回った. すなわち片手に $115 \mathrm{~kg}$ がかかった時である. 今回の解析において, 安 全率は弾性限界を元に算出しているため，この条件下において補助具がすぐに壊れる事はなく，部品の一部に塑 性変形が起きるだけである.また, 実際の移乗動作時には片手に $100 \mathrm{~kg}$ を越える荷重がかかることは発生し難い. しかし衝撃荷重などを考慮した場合，安全率が 1.0 を下回るのは安全上，避けた方が良い。そこで安全率の最も 小さかった部品の大きさを変更し, 強度を向上させることとした.

負荷位置の違いについては，荷重，負荷面積が同一条件の場合を比較すると，負荷が中央の時に最も応力が大 きくなった。これは両端支持梁における負荷位置と最大応力の関係と一致している. また, 開発した補助具の構 造は，補助具の先端，車いす側の二点を回転支点とした両端支持梁と等価とみることができる. 従って，今回は 
Table 1 Analysis result about load on half plate area

\begin{tabular}{|c|c|c|c|c|c|c|}
\hline Load area & \multicolumn{5}{c|}{ Half plate area } \\
\hline Load position & \multicolumn{3}{|c|}{ Front side } & \multicolumn{3}{c|}{ Wheelchair side } \\
\hline Number of elements & \multicolumn{3}{|c|}{21563} & \multicolumn{3}{c|}{21563} \\
\hline Load [N] & 350 & 690 & 1130 & 350 & 690 & 1130 \\
\hline Maximum equivalent stress [MPa] & 17.4 & 34.3 & 56.1 & 50.6 & 99.7 & 163.2 \\
\hline Maximum displacement [mm] & 0.10 & 0.20 & 0.32 & 0.19 & 0.37 & 0.61 \\
\hline Minimum safety factor & 11.9 & 6.0 & 3.7 & 4.4 & 2.2 & 1.4 \\
\hline
\end{tabular}

Table 2 Analysis result about load on palm area

\begin{tabular}{|c|c|c|c|c|c|c|c|c|c|}
\hline Load area & \multicolumn{3}{c|}{ Palm area } & \multicolumn{3}{c|}{ Wheelchair side } \\
\hline Load position & \multicolumn{3}{|c|}{ Front side } & \multicolumn{3}{c|}{ Center } & \multicolumn{3}{c|}{24200} \\
\hline Number of elements & \multicolumn{3}{|c|}{24200} & \multicolumn{3}{c|}{24200} & \\
\hline Load [N] & 350 & 690 & 1130 & 350 & 690 & 1130 & 350 & 690 & 1130 \\
\hline Maximum equivalent stress [MPa] & 7.1 & 14.0 & 23.0 & 84.1 & 165.8 & 277.2 & 62.3 & 122.9 & 234.9 \\
\hline Maximum displacement [mm] & 0.01 & 0.03 & 0.04 & 0.36 & 0.71 & 1.17 & 0.24 & 0.47 & 0.76 \\
\hline Minimum safety factor & 15.0 & 14.8 & 9.0 & 3.0 & 1.5 & 0.9 & 3.7 & 1.9 & 1.1 \\
\hline
\end{tabular}

Table 3 Analysis result about load on hip area

\begin{tabular}{|c|c|c|c|c|c|c|c|c|c|}
\hline Load area & \multicolumn{9}{|c|}{ Hip area } \\
\hline Load position & \multicolumn{3}{|c|}{ Front side } & \multicolumn{3}{|c|}{ Center } & \multicolumn{3}{|c|}{ Wheelchair side } \\
\hline Number of elements & \multicolumn{3}{|c|}{21629} & \multicolumn{3}{|c|}{24780} & \multicolumn{3}{|c|}{24374} \\
\hline Load $[\mathrm{N}]$ & 350 & 690 & 1130 & 350 & 690 & 1130 & 350 & 690 & 1130 \\
\hline Maximum equivalent stress [MPa] & 8.5 & 23.7 & 27.9 & 57.6 & 113.5 & 185.9 & 55.5 & 109.3 & 179.0 \\
\hline Maximum displacement [mm] & 0.02 & 0.06 & 0.07 & 0.17 & 0.34 & 0.56 & 0.11 & 0.22 & 0.35 \\
\hline Minimum safety factor & 15.0 & 8.7 & 7.4 & 4.3 & 2.2 & 1.3 & 4.5 & 2.3 & 1.4 \\
\hline
\end{tabular}

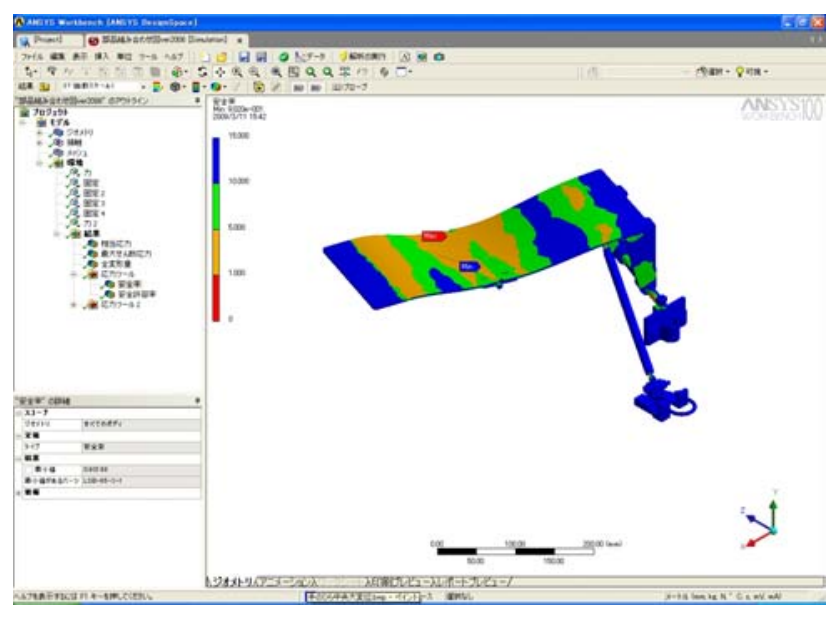

Fig.12 Analysis result of safety factor

(Palm area, Center, $1130 \mathrm{~N}$ )

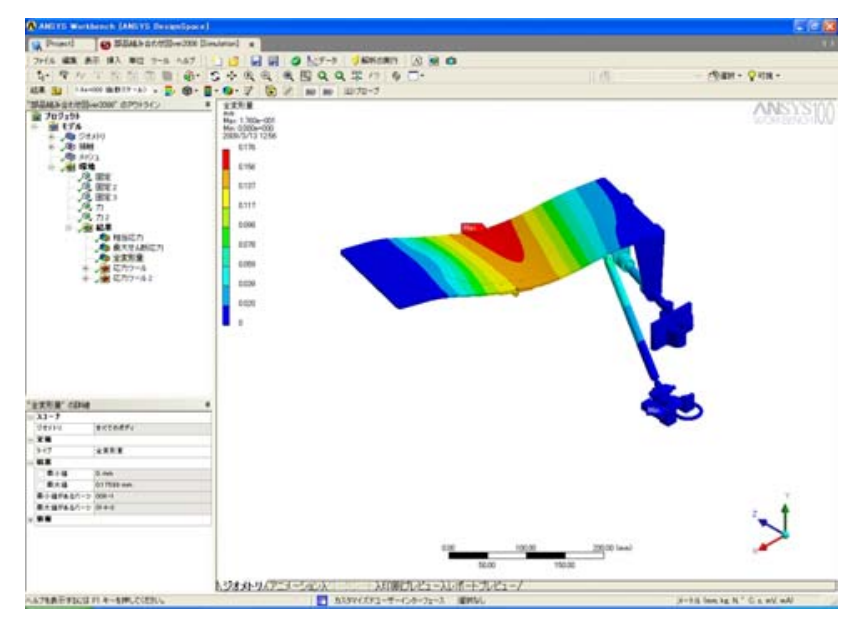

Fig.13 Analysis result of displacement (Hip area, Center, $350 \mathrm{~N}$ )

拡張座面上の 3 力所に負荷がかかった場合を想定して解析を行ったが，任意の位置に負荷がかかった場合の応力 については両端支持梁の応力分布を元に類推することが可能である. 


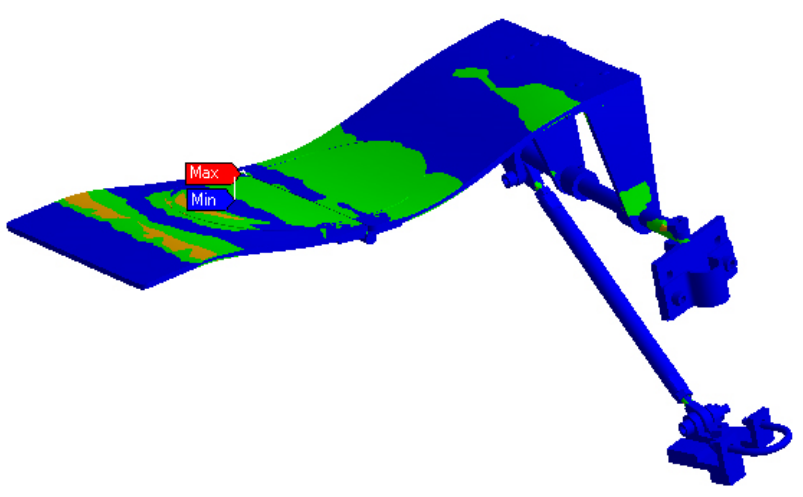

Fig.14 Stress concentration at the plate

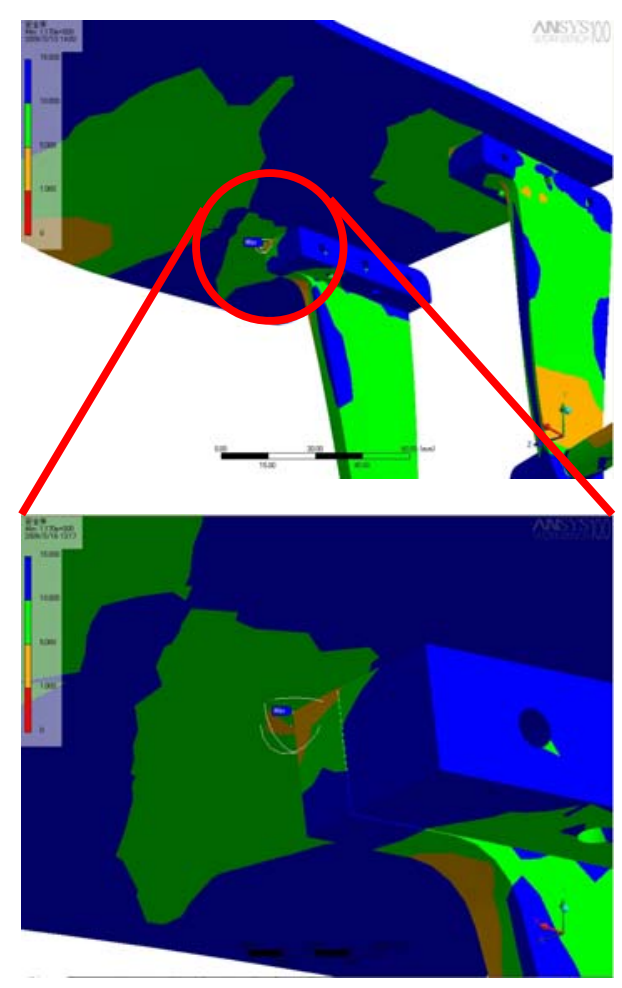

Fig.15 Stress concentration at the attachment parts

荷重面積については一般的に負荷面積が大きい方が，荷重が分散して応力が小さくなる．しかし，板半面への 負荷と臀部面積への負荷を比べた場合, 負荷位置が移動先側ならびに車い寸側においては臀部に比べて面積の大 きい板半面への負荷時の方が高い応力が発生している.この原因としては負荷位置への依存が考えられる. 今回 の補助具は両端支持梁に近い構造であるため, 中央付近にかかる荷重の影響が大きい，そのため移動先側，車い 寸側に荷重が集中した場合には負荷面積が小さくても応力が小さくなると思われる．逆に，板半面に負荷がかか った場合，負荷を受ける面積は大きくても中央部付近にも割合的に負荷がかかるので，その影響で高い応力が発 生したと考えられる.

負荷の集中寸る部品としては図 14 に示寸座面部品周辺ならびに図 15 の固定部品周辺があった. 図 14 の座面部 品については両端支持梁における最も応力が高くなる場所と同じである. 図 15 の部品については拡張座面が水平 時には特に問題ないが，拡張座面が上向きあるいは下向きに角度が少しでもつくと，固定部品のカドにおいて応 力集中が発生している. 安全率が 1.0 を上回っているが応力集中は好ましくないので改善案としてはカド部分を $\mathrm{R}$ 加工する, 固定部品と拡張座面との接触面積を大きくする方法がある. 今回は部品を再設計し, 接触面積を増 やすことで応力集中を回避した。

\section{5. 試作と動作の確認}

\section{$5 \cdot 1$ 試作}

設計を元に試作を行った．車いすに取り付けた状態を図 16 に示す. 材質は可動部の軸周辺がステンレス鋼, 座 面等はアルミ合金とした，大きさは収納時（図 16(b)）が縦 $230 \mathrm{~mm} \times$ 厚さ $40 \mathrm{~mm}$ である．展開時（図 16(a)）に は座面として幅 $150 \mathrm{~mm} \times$ 長さ $400 \mathrm{~mm}$ となる. 収納時には, 最も低い位置となる拡張座面端と床面との間には $150 \mathrm{~mm}$ の隙間ができる. また, 補助具は前輪キャスタの横に収納される. 従って, あまり高くない段差を自力 で乗り越える際 (キャスタ上げ時), 補助具下に十分な隙間があり, かつ前輪キャスタと一緒に持ち上げられてい るので補助具が段差に干渉寸ることはない. 2 枚の折りたたまれた拡張座面については, 磁石による固定を行っ た。 これにより収納時は折りたたまれた状態が保たれ，展開についても特に機構を動作する必要なく容易に開く ことができる. 機構を有していないのでシンプルな構造にもなった. 

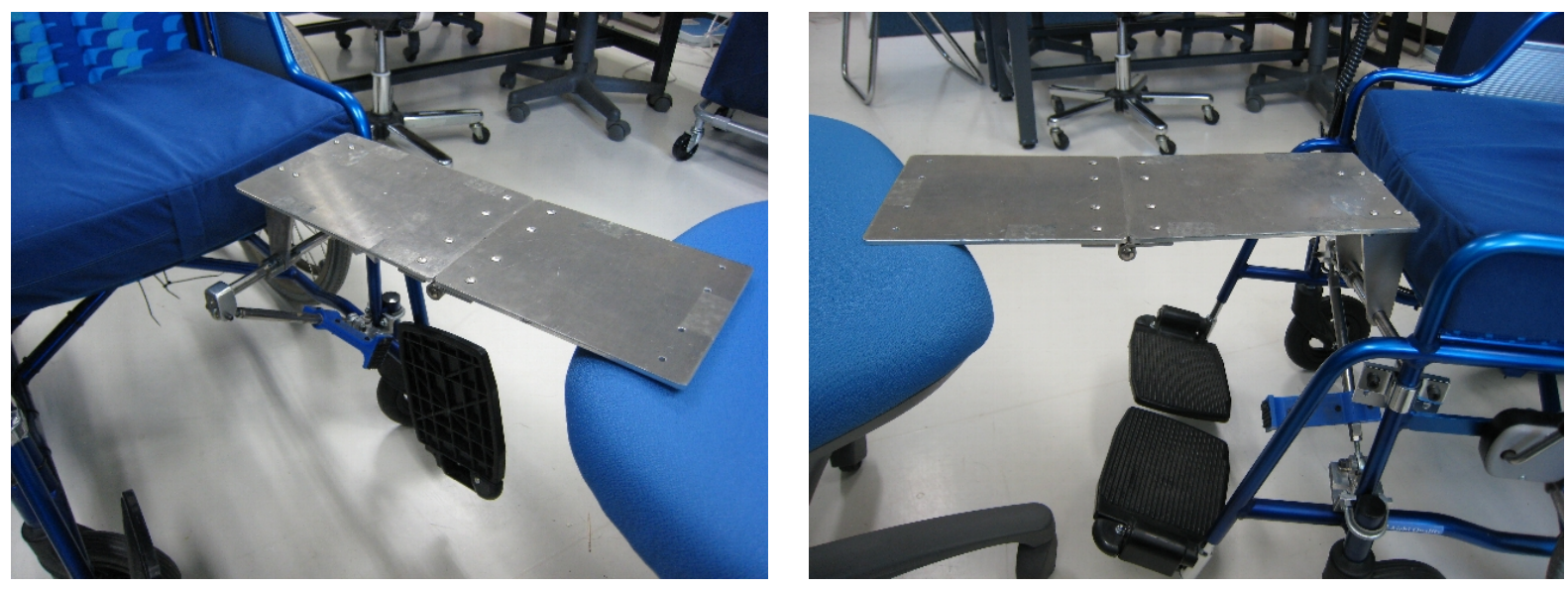

(a) Spread
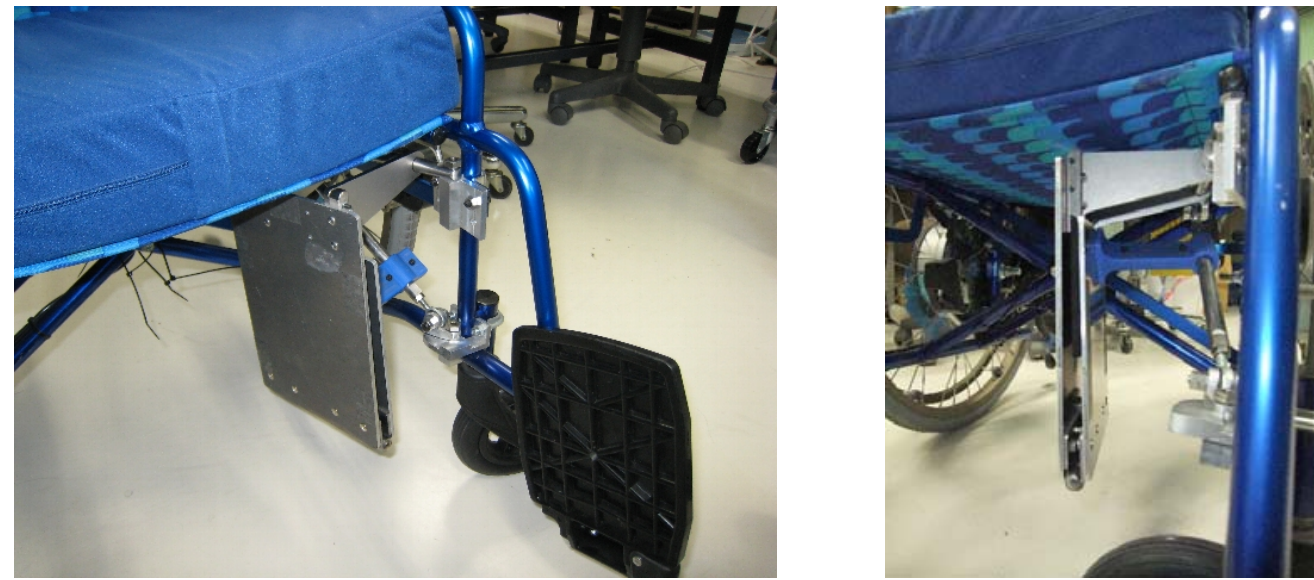

(b) Fold

Fig. 16 Developed transfer aid

\section{$5 \cdot 2$ 展開動作の確認}

試作した補助具の動作について動作確認を行った。 まず開発した補助具を実際に車い寸に取り付けて動作を確 認した. 取り付けについては前述の通り, 車いすへの加工等を行わず，市販されている一般的な車いす本体フレ ームへの挟み込みによって問題なく行う事ができた.

次に取り付けた状態で展開, 収納動作を行えるかを確認した. その様子を図 17 に示寸. 収納状態から展開完了 するまで問題なく行えた. 収納についても展開と逆の手順で同様に問題なく動作を行えた. また, 補助具を取り 付けた状態での車い寸の折りたたみも問題なく行えた．補助具上に乗り，体重をかけて摇らしても破損寸ること もなく強度的にも特に問題はなかった。

\section{6. モニタ評価による補助具効果の確認}

開発した移乗補助具の効果と有用性を調べるため, 車い寸使用者によるモニタ評価を行った。評価項目として は移乗時にかかる負担（体圧分布）の測定と移乗に要した時間測定，移乗中の安定性の確認，使用感の聞き取り 調査を行った. モニタ評価については地元リハビリテーションセンターに協力を仰ぎ, 作業療法士の方と事前相 談をし，また評価にも立ち会ってもらい十分な安全配慮のもとで行った．また，施設倫理委員会での承認をもら い，被験者への主旨や評価内容の十分な説明，承諾書等の諸手続，測定結果に関する個人情報の取り扱いに関し ても取り決めを行ってモニタ評価を行った.

体圧分布の測定にはニッタ株式会社 BPMS 体圧分布測定システムと感圧シート BIG-MAT2000P3BS を用いた. また，感圧シート表面が滑りにくい素材であったため，感圧シート表面には摺動素材（テフロンシート）を貼り 

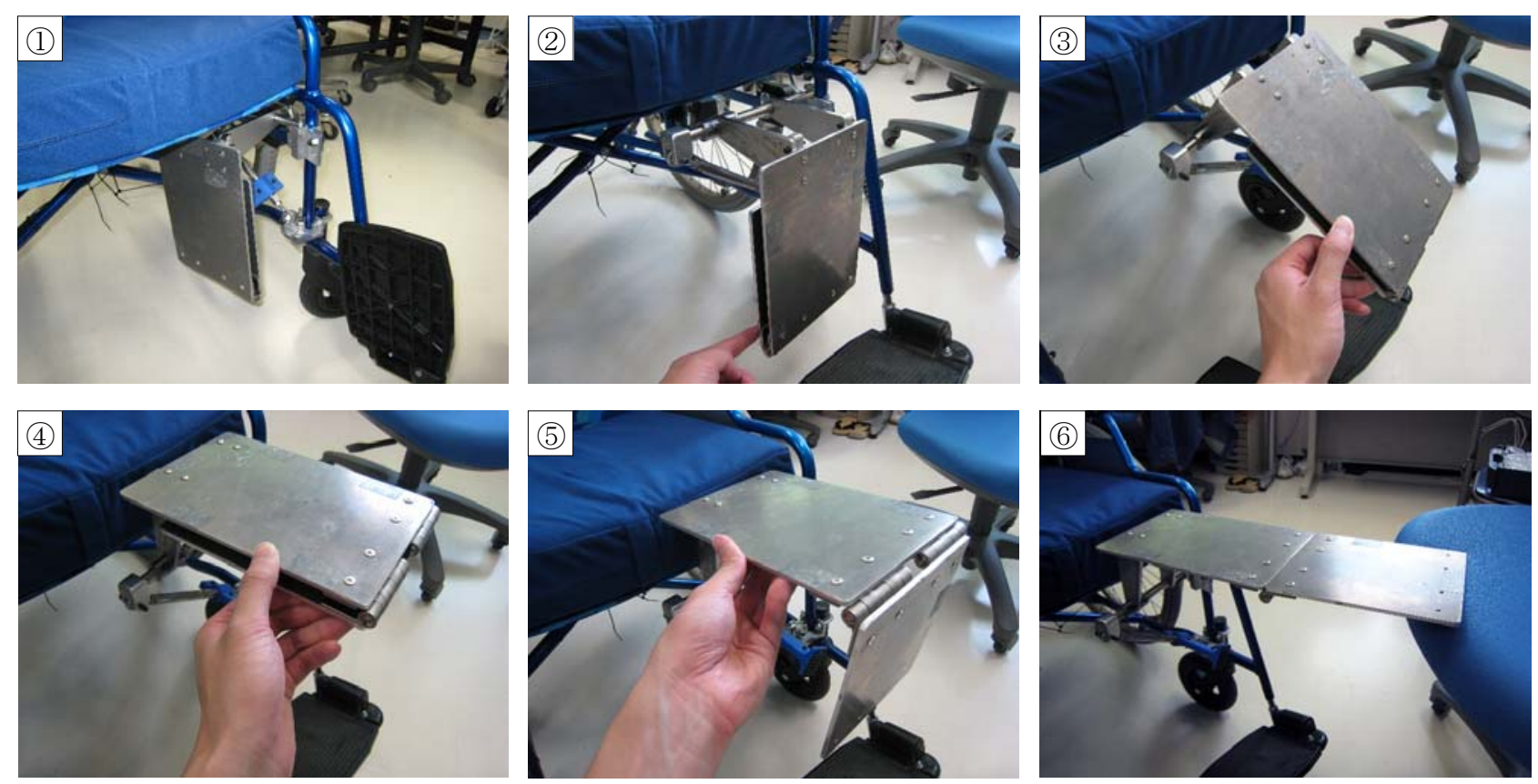

Fig. 17 Motion of spread about developed transfer aid

付けて測定を行った。なお，今回は移乗動作の確認を主体に行ったので展開，収納動作については行ってもらわ なかった。

モニタ評価には 4 名の車い寸使用者に参加してもらった．表 4 に被験者の障害と普段の移乗方法，障害の度合 い（上肢能力, 座位保持能力, 手指能力）を，また表 5 に移乗に関係する被験者の能力を示寸. 座位保持能力に ついては手を使わずに座位を保持できるかと，軽く押されても座位を維持できるかによる判断，手指能力につい ては物の把持が可能かどうかを判断基準とした. モニタ評価としては一般的な移乗補助具 (トランスファボード) を使用した場合と，開発した移乗補助具を使用した場合での移乗を評価した．また，移乗動作としてはベッドか ら車い寸，車い寸からベッドのそれぞれについて行った．表６にモニタ評価を行った結果を示す．

能力測定の後, 実際に移乗を行ってもらった結果, 開発した移乗補助具での移乗を 4 名中 3 名が行えた. また, 3 名とも 1 人での移乗を行えた。被験者 B に関してはトランスファボードによる移乗においても安定せず, 安全 を考慮して補助具での移乗を行わなかった。他の 3 名に関しては，開発した補助具を使用しての移乗を概秝 15

Table 4 Ability of subjects

\begin{tabular}{|c||c|c|c|c|c|c|c|}
\hline \multirow{3}{*}{ Subjects } & \multicolumn{4}{|c|}{ Upper limb } & \multicolumn{2}{c|}{ Sitting balance } & Hands and fingers \\
\cline { 2 - 8 } & Forward & Side & $\begin{array}{c}\text { Extend } \\
\text { overhead }\end{array}$ & Resistance & Keep & Resistance & Grip \\
\hline \hline A & $\bigcirc$ & $\bigcirc$ & $\triangle$ & - & $\triangle$ & $\times$ & $\bigcirc$ \\
\hline B & $\bigcirc$ & $\bigcirc$ & $\triangle$ & $\triangle$ & $\triangle$ & $\times$ & $\times$ \\
\hline C & $\bigcirc$ & $\bigcirc$ & $\bigcirc$ & - & $\bigcirc$ & $\bigcirc$ & $\bigcirc$ \\
\hline D & $\bigcirc$ & $\bigcirc$ & $\bigcirc$ & $\bigcirc$ & $\triangle$ & $\times$ & $\times$ \\
\hline
\end{tabular}

Table 5 Subjects disability and transfer method

\begin{tabular}{|c||c|c|c|}
\hline Subjects & Levels of spinal cord injury & Transfer aids for daily use & Transfer direction \\
\hline \hline A & Th2 & Transfer board, & Cross Direction \\
\hline B & C6IIA & Transfer board & Forward Direction \\
\hline C & C7 & Non-use & Cross Direction \\
\hline D & C7IIIB & Non-use & Forward Direction \\
\hline
\end{tabular}


Table 6 Results of measurement

\begin{tabular}{|c|c|c|c|c|c|c|c|c|}
\hline \multirow{3}{*}{ Subjects } & \multicolumn{4}{|c|}{ Transfer board } & \multicolumn{4}{|c|}{ Developed transfer aid } \\
\hline & \multicolumn{2}{|c|}{ Time [s] } & \multirow{2}{*}{$\begin{array}{l}\text { Transfer } \\
\text { direction }\end{array}$} & \multirow[b]{2}{*}{ Stability } & \multicolumn{2}{|c|}{ Time $[\mathrm{s}]$} & \multirow{2}{*}{$\begin{array}{l}\text { Transfer } \\
\text { direction }\end{array}$} & \multirow[b]{2}{*}{ Stability } \\
\hline & $\begin{array}{c}\quad \text { Bed } \\
\rightarrow \text { Wheelchair }\end{array}$ & $\begin{array}{c}\text { Wheelchair } \\
\rightarrow \text { Bed }\end{array}$ & & & $\begin{array}{c}\text { Bed } \\
\rightarrow \text { Wheelchair }\end{array}$ & $\begin{array}{c}\text { Wheelchair } \\
\rightarrow \text { Bed }\end{array}$ & & \\
\hline A & 33 & 19 & Cross & Unstable & 15 & 9 & Cross & Stable \\
\hline $\mathrm{B}$ & 91 & 65 & Forward & Incomplete & - & - & - & - \\
\hline $\mathrm{C}$ & 6 & 5 & Cross & Stable & 15 & 16 & Cross & Stable \\
\hline $\mathrm{D}$ & 7 & 19 & Forward & Unstable & 10 & 13 & Cross & Stable \\
\hline
\end{tabular}

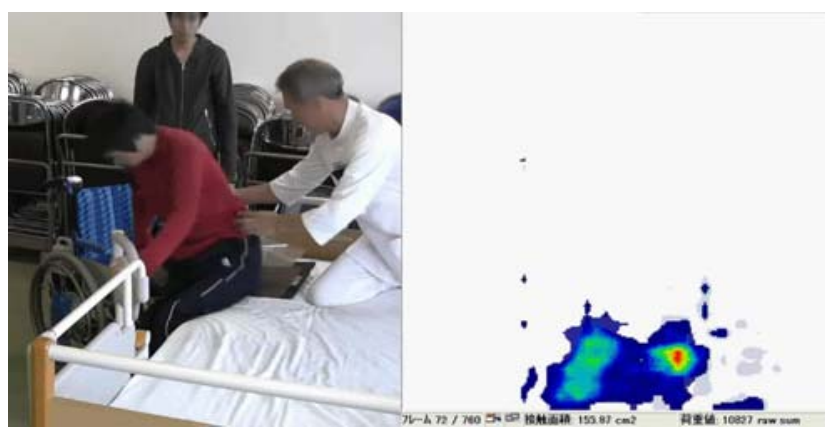

(a) Using transfer board

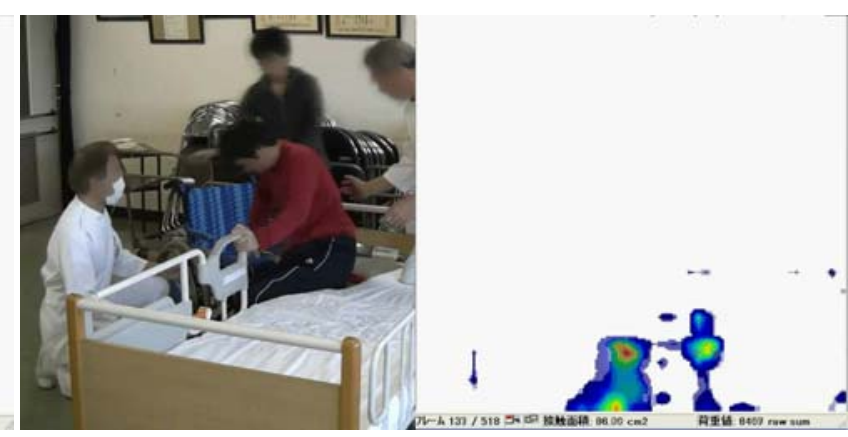

(b) Using developed transfer aid

Fig.18 Body pressure while transfer

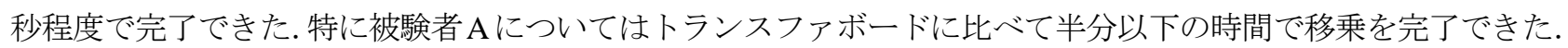
被験者 C に関しては日常で自力での移乗を行っており，また普段は移乗補助具を使用していないため, 補助具そ のものを使い慣れていないことから補助具での移乗時間が延びたと思われる. 被験者 D に関して, 日常では前移 乗を行っており，一般的な補助具では横移乗を行えなかったが，開発した補助具を使用した際には横移乗を問題 なく行えた。

移乗中の体圧分布変動の様子の一部について，トランスファボードによる移乗時を図 18(a)に，開発した補助具 による移乗時を図 18(b)に示す．トランスファボードの場合には接触面積が広くなり，体重が分散してかかってい るのが見てとれた。一方，開発した補助具についてはトランスファボードに比べてわずかに高負荷領域の割合が 多かった．この原因としては補助具の面積がトランスファボードに比べて狭いことが考えられる．また，トラン スファボードは材質が柔らかいため，負荷の高い所では変形して全体に負荷が分散されるが，開発した補助具の 拡張座面の材質はアルミなので，変形することはなく接触面の負荷がそのまま反映される．ただ，最高圧力や圧 力分布，傾向にはあまり大きな違いはないので，補助具での移乗に関してはトランスファボードの移乗と同程度 の負荷で移乗を行えると考えられる.

移乗後の聞き取り調查において，トランスファボードでの移乗時には，材質の柔らかさから手で体幹を支持し ようと踏ん張った際に踏ん張りがきかず，安定した姿勢を維持できないという意見があった．トランスファボー ドの材質は樹脂材料のポリエチレンが用いられており変形しやすい. 移乗時に破断することはなかったが図 19 のように両端支持の状態で中央に座ると大きくたわむ. このため移乗動作の際に手や臀部をついた所が変形し， 不安定な姿勢になる可能性がある。一方, 開発した補助具はアルミでできているため変形量がほとんどなく, 高 負荷がかかっても変形せず安定して移乗が行える. 従って変形しにくさから開発した補助具はトランスファボー ドより安定した移乗を行えると考えられる.

この他の意見として補助具の座面幅がトランスファボードに比べて狭い事に対する意見がいくつか挙がった. 今回使用したトランスファボードの幅が $325 \mathrm{~mm}$ なのに対して開発した補助具の座面幅は $150 \mathrm{~mm}$ である. 幅が 広いと移乗時に手をつく場所に余裕ができ, 心理的にも安心感が増す. また, 横移乗だけでなく前移乗も行える. 


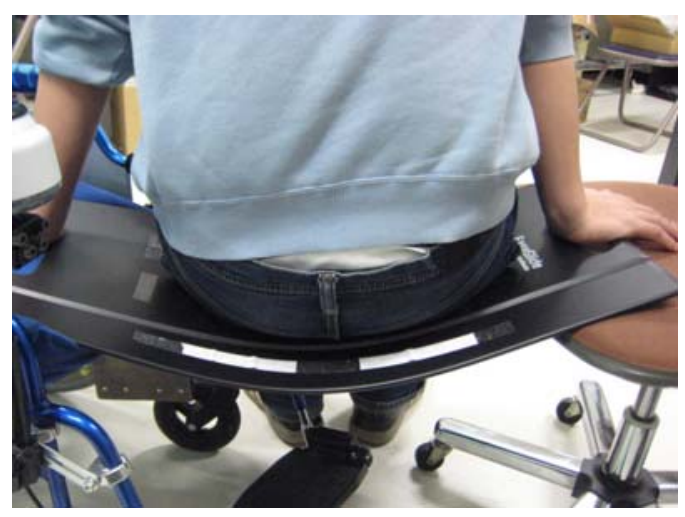

(a) Transfer board

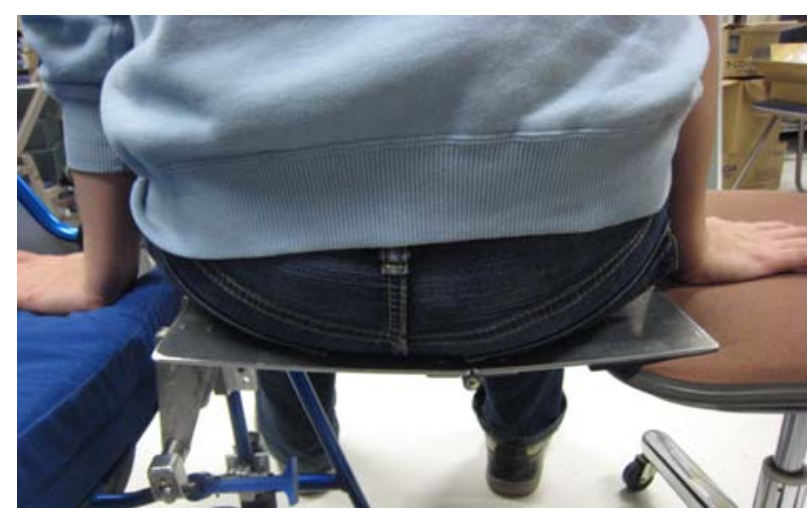

(b) Developed transfer aid

Fig. 19 Deformation by load

しかし，座面幅が広がると足を取り回すためのスペースが狭くなり，移乗動作に支障をきたす，本評価中も，卜 ランスファボードを使用した移乗時に，移乗先への最後の移動の際に足が車いすやベッドに干渉して移乗を妨げ ている様子が伺えた。一方，開発した補助具は足の取り回しを考慮して幅を決定してある．補助具での移乗の際 には足の取り回しでもたつくことはなかった．面積が狭いため手をつく場所に限りがありその事で被験者が不安 を感じるという意見もあったが, 今回移乗を行った被験者は開発した補助具による移乗をあまり練習していない. それにもかかわらず安定した移乗を行えたので，練習を行ったり慣れたりすることで幅が狭いことに関しては改 善が図れると考えられる.

\section{7. 結 言}

本研究において，車い寸使用者が一人で移乗を行える自立型移乗補具について開発した．車い寸に固定して使 用するため，持ち運ぶ必要がない．またアタッチメント方式を採用しているため車い寸を改造しなくても容易に 固定できる，走行時は車い寸座面下に折りたたんで収納し，移乗時に展開して使用するためコンパクトで，また 車い寸の折りたたみ機能を阻害することもない．試作したものを車い寸使用者に使用してもらいその効果を確認 した所，移乗にかかる時間を概补 10〜15 秒に短縮できた。 また，前移乗しか行えなかった被験者が横移乗でも移 乗を行えるようになったことも確認できた．体圧分布の測定結果より，座面幅がトランスファボードに比べて小 さくなったが，体圧分布の変化や傾向に大きな違いはなかったため負担の増加はなかった．また，座面部分の材 質をアルミにしたことにより，体重によるたわみを大きく抑えることができ，安定性を大きく向上することがで きた，以上により，本研究で提案する補助具の有用性を確認できた．今後は補助具の展開，収納動作を使用者が 座った状態で容易に行えるようにするなど，使い易さの改善を進めていく予定である．また，座面幅が狭いこと に対して，形状を工夫するなどして足の取り回しを行いやすく，から座面幅を大きくすることも検討していく.

\section{謝 辞}

本研究の一部は厚生労働科学研究費補助金（障害保健福祉総合研究事業）ならびに JSPS 科研費 22700587 の助 成を受けたものである。ここに記して謝意を表す。

\section{文献}

青野雅人, 田中理, 飯島浩, 宮本晃, 荒井孝雄, 太田穹郎, 宮田孝文, 中島博光, 「こまわりさん」をべースにした

新型移乗介助機器の開発（第 2 法）, 第 17 回リ八工学カンファレンス講演論文集 (2002), pp.415-418.

一般財団法人保健福祉広報協会, 2011 年度版福祉機器ガイドブック(2011), p.125.

井上剛伸, 山崎信寿, 移乗介助機器使用時の身体的負担, バイオメカニズム学会誌, Vol.25, No.3（2001）,

pp.123-129.

日本規格協会, JIS ハンドブック 38 福祉（2001）, pp.132-133. 
勝平純司, 冨田早基, 原口辰也, 原田紗希, 石川悦子, 久保和也, 丸山仁司, 移乗補助具の使用, 種類, 使用姿位の 違いが移乗介助動作時の腰部負担に与える影響, 人間工学, Vol.46, No.2 (2010), pp.157-165.

木下功士, 小泉邦雄, 抱上げ移乗器具の研究 (移乗介助作業の抱上げ動作に関する理論的考察), 日本機械学会誌, Vol.73, No.730 (2007), pp.1661-1666.

小林裕介, 障害者の自立支援のための移乗システムの研究, 厚生労働科学研究費補助金障害保健福祉総合研究事 業総合研究報告書(2010), pp.1-41.

茂木伸之, 安田智美, 三澤哲夫, 補助具使用と介護動作に関する実験的研究, 労働科学, Vol.88, No.3（2012）, pp.81-93.

佐々木秀明, 勝平純司, 渡辺仁史, 西條富美代, 齋藤昭彦, 移乗補助器具を用いた移乗介助動作における介助者の 腰部負担について, 理学療法学, Vol.34, No.7 (2007) , pp. 294-301.

佐藤帆紡, 川畑共良, 田中文英, 山海嘉之, ロボットスーツ HAL による移乗介助動作の支援, 日本機械学会誌, Vol.76, No.762 (2010), pp.227-235.

\section{References}

Aono, M., Tanaka, O., Iijima, H., Miyamoto, A., Arai, T., Ohta, K., Miyata, T. and Nakajima, H., The development of the new transfer aid that used a "KOMAWARISAN" as a base, Proceedings of The 17th Japanese Conference on the Advancement of Assistive Rehabilitation Technology (2002), pp.415-418 (in Japanese).

Health and Welfare Information Association, Welfare toll guidebook 2011, (2011), p. 125 (in Japanese).

Inoue, T. and Yamazaki, N., Physical loads during using transfer aids, Journal of the Society of Biomechanisms, Vol.25, No.3 (2001), pp.123-129 (in Japanese).

Japanese Standards Association, JIS handbook 38 welfare (2001), pp. 132-133 (in Japanese).

Katsuhira, J., Tomita, S., Haraguchi, T., Harada, S., Ishikawa, E., Kubo, K. and Maruyama, H., Effect of use and type of assistive devices and posture while using them on the low back load in transferring tasks, The Japanese journal of ergonomics, Vol.46, No.2 (2010), pp.157-165 (in Japanese).

Kinoshita, K., and Koizumi K., Study on transfer instrument (Theoretical consideration on lift up motion of transfer operation), Journal of the Japan Society of Mechanical Engineers, Vol.73, No.730 (2007), pp.1661-1666 (in Japanese).

Kobayashi. Y., Research of transfer system for disabled by self-help, Report of the Health Labour Sciences Research Grant Comprehensive Research on Disability Health and Welfare (2010), pp.1-41 (in Japanese).

Motegi, N., Yasuda, S. and Misawa, T., Experimental study of assistant aids and a new nursing method in nursing care work, The journal of science of labour, Vol.88, No.3 (2012), pp.81-93 (in Japanese).

Sasaki, H., Katsuhira, J., Watanabe, H., Saijou, F. and Saito, A., Low back load of caregiver during transfer movement using assistive devices, RIGAKU RYOHOGAKU, Vol.34, No.7 (2007), pp.294-301 (in Japanese).

Satoh, H., Kawabata, T., Tanaka, F. and Sankai Y., Transferring-care assistance with robot suit HAL, Journal of the Japan Society of Mechanical Engineers, Vol.76, No.762 (2010), pp.227-235 (in Japanese). 